\title{
PODSTAWY KONCEPCJI ZARZADZANIA ZATRZYMYWANIEM WARTOŚCI PRZEZ PRZEDSIĘBIORSTWO
}

DOI: 10.33141/po.2019.11.01

\section{Bogusław Gulski}

\section{Wprowadzenie}

D rowartościowy paradygmat zarządzania od kilkudziesięciu lat wpływa zarówno na praktykę, jak i teorię zarządzania. Konsekwencją tego jest fakt, że generowanie i zatrzymywanie wartości przez przedsiębiorstwo są coraz bardziej obecne $\mathrm{w}$ dyskusjach i publikacjach z zakresu zarządzania strategicznego (Ramu, Sunitha, 2016). Jego wpływ widać m.in. w opiniach takich jak wyrażona przez A.K. Koźmińskiego i D. Jemielniaka (2008, s. 430): „zarządzanie wartością jest jednym z podstawowych zadań naczelnego kierownictwa każdej organizacji”. W okresie dominacji wspomnianego paradygmatu następowała ewolucja odwołującej się do niego koncepcji zarządzania wartością, począwszy od drugiej połowy lat 80., gdy w Stanach Zjednoczonych za nadrzędny cel korporacji uważano maksymalizację wartości dla akcjonariuszy, a skończywszy na koncepcji zrównoważonego zarządzania wartością, w której występuje zbieżność koncepcji zarządzania wartością oraz koncepcji społecznej odpowiedzialności i koncepcji zrównoważonego rozwoju. Nazwa zrównoważone zarządzanie wartością trafnie oddaje specyfikę wspomnianej koncepcji, w której osiąganie celów ekonomicznych jest ściśle związane z realizacją celów społecznych (Jaki, 2016).

Wydaje się, że zrównoważone zarządzanie wartością można powiązać $\mathrm{z}$ dwoma teoriami: interesariuszy i legitymizacji. Ten związek polega na tym, że realizując cele społeczne, przedsiębiorstwo zarazem realizuje oczekiwania swoich interesariuszy i w ten sposób zwiększa prawdopodobieństwo uzyskania z ich strony legitymizacji i jej pozytywnych skutków. Należy jednak pamiętać, że spełnienie oczekiwań interesariuszy zależy od dysponowania przez przedsiębiorstwo dostatecznie dużą wartością.

$\mathrm{W}$ artykule podjęto próbę zaproponowania koncepcji, która ułatwi rozwiązywanie części z problemów, które pojawią się przed przedsiębiorstwami zamierzającymi stosować założenia zrównoważonego zarządzania wartością. Tą koncepcją jest zarządzanie zatrzymywaniem wartości przez przedsiębiorstwo. Można określić ją jako instrument zarządzania, który ma stworzyć warunki do tego, by przedsiębiorstwo dysponowało dostatecznie dużą wartością konieczną do spełnienia oczekiwań swoich interesariuszy i zapewnienia sobie legitymizacji.

Wskazany zamiar wynika z praktycznego charakteru nauk o zarządzaniu i może być rozpatrywany w kontekście użyteczności konceptualnej (Hensel, 2017, s. 36), ponieważ opisana koncepcja prezentuje zjawiska związane $\mathrm{z}$ wartością $\mathrm{w}$ nowej, szerszej perspektywie, pozwalając zarządzającym na lepsze zrozumienie relacji między zjawiskami związanymi z wartością.

Zaprezentowaną koncepcję wyprowadzono $\mathrm{z}$ następujących przesłanek:

1. Sprawne funkcjonowanie przedsiębiorstwa zależy od uzyskania legitymizacji ze strony interesariuszy.

2. Uzyskanie legitymizacji wymaga spełnienia oczekiwań interesariuszy, co jest uwarunkowane dysponowaniem odpowiednio dużą wartością, którą przedsiębiorstwo powinno zatrzymać.

3. Wartość zatrzymana przez przedsiębiorstwo zależy od wielkości: a) wartości wygenerowanej przez przedsiębiorstwo, b) wartości przejętej przez przedsiębiorstwo, c) wartości obronionej przed zawłaszczeniem przez inne podmioty.

4. Przedsiębiorstwo powinno zarządzać aktywnościami składającymi się na zatrzymywanie wartości.

Zastosowanie opisanej koncepcji ma zapewnić możliwość dysponowania wartością przez przedsiębiorstwo w celu zaspokojenia oczekiwań jego interesariuszy, by zwiększając stopień swojej legitymizacji oraz uzyskując jej pozytywne rezultaty, uniknąć negatywnych skutków braku legitymizacji.

Artykuł składa się z dwu zasadniczych części. W pierwszej, wprowadzającej, składającej się ze względnie krótkich fragmentów, dokonano ogólnej charakterystyki pojęć i zjawisk, do których odwołano się w powyższych przesłankach. W części drugiej, prezentującej tytułową koncepcję i kluczowej z punktu widzenia realizacji celu artykułu, usytuowano zarządzanie zatrzymywaniem wartości w kontekście ewolucji zarządzania wartością oraz zdefiniowano tę koncepcję. Następnie zaprezentowano aktywności składające się na zarządzanie zatrzymywaniem wartości, odwołując się zarówno do literatury przedmiotu, jak i wyników badań autora. Podsumowaniem rozważań nad wspomnianymi aktywnościami jest model zarządzania zatrzymywaniem wartości przez przedsiębiorstwo.

Celem artykułu jest sformułowanie, charakterystyka oraz zaprezentowanie $\mathrm{w}$ postaci modelu koncepcji zarządzania ukierunkowanego na zatrzymywanie wartości przez przedsiębiorstwo. Artykuł ma charakter metodyczny. Do jego opracowania wykorzystano podejście dedukcyjne oraz studia literaturowe i wyniki badań empirycznych autora. 


\section{Legitymizacja przedsiębiorstw}

L egitymizacja organizacji jest traktowana jako jeden z kluczowych czynników warunkujących relacje między organizacją a otoczeniem (Hensel, 2017, s. 11). Oznacza ona „upowszechnione wrażenie lub założenie, że aktywności podejmowane przez podmiot są pożądane, właściwe lub stosowne w jakimś społecznie skonstruowanym systemie norm, wartości, przekonań i definicji" (Suchman, 1995, s. 574 za Hensel, 2017, s. 11). Podmioty cechujące się wysokim poziomem legitymizacji mają dzięki temu co najmniej: 1) łatwiejszy dostęp do zasobów, 2) wsparcie podmiotów $z$ otoczenia w rywalizacji z innymi podmiotami, 3) uczestników o większym poziomie satysfakcji. Natomiast niski poziom legitymizacji może skutkować: 1) brakiem wsparcia ze strony państwa czy samorządów, 2) potrzebą ciągłego odpierania zarzutów ze strony podmiotów kwestionujących sens funkcjonowania organizacji, 3) trudnościami w rekrutacji pracowników, 4) cynizmem aktorów organizacyjnych (Hensel, 2017, s. 11). W tym kontekście należy przywołać pogląd, że przedsiębiorstwa (kierownicy) powinny „wyjść naprzeciw” interesom tych podmiotów, na które wpływają przez funkcjonowanie instytucji. Autorzy C. Haksever, R. Chaganti i R.G. Cook (2004) przyjęli założenie, że przedsiębiorstwo może generować wartość dla różnych grup interesariuszy, jeśli oni tego oczekują od przedsiębiorstwa. Stwierdzili, że kluczowymi interesariuszami przedsiębiorstwa są: 1) właściciele (akcjonariusze), 2) pracownicy, 3) klienci, 4) dostawcy i 5) społeczeństwo jako całość, w szczególności społeczność lokalna. Wspomniane „wyjście naprzeciw” może skutkować legitymizacją przedsiębiorstwa.

\section{Generowanie wartości}

$\mathbf{P}$ rymat generowania wartości nad innymi celami przedsiębiorstw jest jednym ze skutków dominacji finansjalizacji w środowisku przedsiębiorstw. P. Verdin i K. Tackx (2015) określili syntetycznie wartość jako postrzeganą korzyść dla klienta. Tak rozumiana wartość poprawia jakość życia końcowego konsumenta (w relacji B2C) albo powiększa zyskowność przedsiębiorstwa (w relacji B2B). Z kolei C. Bowman i V. Ambrosini (2000) powiązali wartość z zaspokajaniem potrzeb klientów i w konsekwencji posłużyli się pojęciem „wartość użytkowa”. Jest ona wysoce zindywidualizowana i ze swej istoty subiektywna, co oznacza, że różni klienci mogą odmiennie postrzegać wartość użytkową tego samego produktu. Obok wartości użytkowej wskazuje się także inne rodzaje wartości generowanej przez przedsiębiorstwo, np. J.B. Smith i M. Colgate (2007) wyróżnili cztery główne typy wartości dla klienta, jakie mogą zostać wygenerowane:

1. Wartość funkcjonalna, którą tworzą: cechy samego produktu, zakres, w którym produkt jest przydatny i realizuje pożądane cele klienta.

2. Wartość doświadczenia: zakres, w którym produkt tworzy odpowiednie doświadczenia, uczucia i emocje dla klienta.
3. Wartość symboliczna: zakres, w którym klienci przywiązują się albo przypisują psychologiczne znaczenie do produktu (ten rodzaj wartości bywa określany jako wartość emocjonalna).

4. Wartość poświęcenia: koszt albo poświęcenie, które byłyby związane $\mathrm{z}$ użyciem produktu.

Wydaje się, że ocena innych niż wartość użytkowa rodzajów wartości również cechuje się subiektywizmem, na przykład wartość doświadczenia jest cenniejsza z punktu widzenia indywidualnego odbiorcy niż z punktu widzenia organizacji.

W literaturze przedmiotu jest używane pojęcie „wartość wymienna”, które oznacza ilość środków pieniężnych (cenę) otrzymywaną przez sprzedającego od kupującego w momencie transakcji, tzn. wymiany między sprzedawcą i kupującym (Bowman, Ambrosini, 2000). W większości sytuacji wartość wymienna produktu jest mniejsza niż jego wartość użytkowa (Priem, 2001). Można sądzić, że to zjawisko występuje także w przypadku innych rodzajów wartości.

Kolejny termin, stosowany obok już wymienionych, „wartość wygenerowana" ma charakter agregatowy i jest definiowany jako różnica między ceną, jaką kupujący płacą za produkt końcowy, a kosztem produkcji wyrobu albo dostarczenia usługi (np. Bowman, Ambrosini, 2000; Hoffman, 2015, s. 6).

Rozważając generowanie szeroko rozumianej wartości, należy mieć świadomość istnienia ambiwalencji, a nawet antagonizmów między oczekiwaniami różnych grup interesariuszy. W rezultacie określona aktywność przedsiębiorstwa może generować korzyści dla jednej z grup interesariuszy, a zarazem pomniejszać korzyści innej grupy, a nawet powiększać jej koszty czy ryzyko. Dlatego należy dostrzec i uwzględniać dwojaki charakter procesów zachodzących w przedsiębiorstwie: generowania wartości i niszczenia wartości.

\section{Przejmowanie wartości}

akkolwiek w literaturze przedmiotu do określenia opisywanego procesu używa się z reguły pojęcia „zatrzymywanie wartości”, w artykule używa się zwrotu „przejmowanie wartości” rozumianego jako wzięcie tego (wartości wymiennej) co wcześniej należało do kogoś innego (nabywcy), jako trafniej oddającego istotę procesu. Oznacza to, że przejmowanie wartości, jakkolwiek taki pogląd nie jest formułowany w literaturze expressis verbis, odnosi się do wartości wymiennej. Ta wartość, pomniejszona o koszty wygenerowania wartości (użytkowej i innych) jako wartość zatrzymana wpływa na wynik finansowy przedsiębiorstwa, które może nią dysponować. Przejęta wartość, o ile nie zostanie zawłaszczona przez inne podmioty, umożliwia realizację oczekiwań interesariuszy przedsiębiorstwa.

Przejmowanie wartości bywa opisywane za pomocą innych określeń, takich jak: przywłaszczenie wartości, realizacja wartości, rozproszenie wartości, dystrybucja wartości czy przydział wartości (Fischer, 2011, s. 12). Stosując metaforę, można stwierdzić, że jeżeli wygenerowana wartość oznacza wielkość placka, to wartość przejęta oznacza tę część placka, którą otrzymują podmioty uczestniczące w procesie generowania wartości (Gulati, Wang, 2003, s. 209). 
Biorąc pod uwagę stopień kontroli przedsiębiorstwa, można wyróżnić dwie grupy czynników wpływających na przejmowanie wartości: a) wewnętrzne będące skutkiem decyzji podjętych przez przedsiębiorstwo i będących pod jego kontrolą, b) zewnętrzne będące skutkiem struktury sektora, rynku czy regulacji prawnych, które w krótkim okresie są niezależne od przedsiębiorstwa.

\section{Utrata wartości przez przedsiębiorstwo}

$\mathrm{U}$ trata wartości wygenerowanej przez przedsiębiorstwo zachodzi wskutek zjawiska, które można nazwać zawłaszczaniem wartości. Termin ten oznacza przechwycenie tej wartości, która jest przeznaczona dla innego podmiotu. Zawłaszczanie wartości, w odróżnieniu od przejmowania wartości, ma charakter negatywnie wartościujący.

O podobnym zjawisku pisali różni autorzy, jakkolwiek posługiwali się odmiennymi terminami, np. M. Hoefle (2017) użył pojęcia value extraction, opisując uzyskiwanie przez pewne grupy nieuczciwych przewag na rynku. P. Strebel i S. Cantale (2014) opisali zjawisko, które również nazwali value extraction, ale określili je jako takie przechwytywanie wartości od innych zainteresowanych stron, zarówno na zewnątrz, jak i wewnątrz przedsiębiorstwa, które zachodzi przez manipulowanie procesami konkurencyjnymi na rynku na korzyść tego przedsiębiorstwa. Odwołując się do przywołanej powyżej metafory o tworzeniu i podziale ciasta (Gulati, Wang, 2003, s. 209), P. Strebel i S. Cantale stwierdzili, że jeśli tworzenie wartości zwiększa rozmiary tortu, a zatrzymywanie wartości umożliwia przedsiębiorstwom otrzymanie kawałka tego tortu, to value extraction polega na uzyskaniu większego kawałka poprzez manipulowanie procesem dzielenia tortu.

Badania autora artykułu (Gulski, 2017, r. IV) pozwoliły zidentyfikować sekwencję zachowań przedsiębiorstw dokonujących zawłaszczania wartości, która składa się z: 1) wykreowania nierównowagi organizacyjnej w relacjach z innymi podmiotami, 2) podejmowania zachowań oportunistycznych, 3) przywłaszczenia wartości.

\section{Zarządzanie zatrzymywaniem wartości}

K oncepcja zarządzania wartością ewoluuje. Można to dostrzec m.in. w znaczeniu przypisywanemu terminowi zarządzanie wartością. A.K. Koźmiński i D. Jemielniak stwierdzili (2008, s. 426): „Zarządzanie wartością polega na takim kształtowaniu łańcucha wartości, by zmaksymalizować wartość dodaną tworzoną w organizacji”. Szerszej do tego zagadnienia podszedł K. Obłój (2002, s. 79): „Tworzenie wartości jest jednym elementem równania przewagi konkurencyjnej; drugim jest umiejętność zatrzymania materialnych i niematerialnych korzyści z tego tytułu”. Ten pogląd wydaje się współcześnie dominować. Tezę o konieczności łącznego rozpatrywania generowania i przejmowania wartości wyrazili np. M.E. Raynor i A. Mumtaz (2013), którzy stwierdzili, że przedsiębiorstwa muszą nie tylko utworzyć wartość, ale też przejmować ją w formie dochodów. Podobny pogląd sformułowali C. Ellegard, C.J. Medlin i J. Geersbro (2014), twierdząc, że koncepcje tworzenia i przejmowania wartości są ściśle powiązane.

Wydaje się, że na kolejnym etapie ewolucji zarządzania wartością należy dodatkowo uwzględnić opisane powyżej zjawisko zawłaszczania wartości skutkujące niebezpieczeństwem utraty wartości przez przedsiębiorstwo na rzecz podmiotów pozostających $\mathrm{z}$ nim w relacjach. W konsekwencji można stwierdzić, że przedsiębiorstwo winno jednocześnie: 1) generować wartość, 2) przejmować wartość, 3) podejmować działania obronne przed utratą wartości. Uwzględniając przywołane powyżej zjawisko legitymizacji przedsiębiorstw, która zależy od zaspokojenia oczekiwań interesariuszy oraz niezbędność dysponowania przez przedsiębiorstwo dostatecznie dużą wartością, by zaspokoić te oczekiwania, należałoby raczej posługiwać się pojęciem „zarządzanie zatrzymywaniem wartości”, które można zdefiniować następująco: zarządzanie zatrzymywaniem wartości przez przedsiębiorstwo jest to kompleksowe podejście do zarządzania przedsiębiorstwem, w którym poprzez integrację: generowania wartości, przejmowania wartości oraz obrony przed utratą wartości dąży się do stworzenia warunków do spełnienia oczekiwań interesariuszy przedsiębiorstwa dotyczących wartości dostarczanej im przez przedsiębiorstwo. W sekwencji działań wskazanej w tym określeniu generowanie wartości ma charakter pierwotny w stosunku do przejmowania i obrony przed zawłaszczeniem wartości.

Zarządzanie zatrzymywaniem wartości wymaga w pierwszej kolejności takiego ukształtowaniu procesu generowania wartości, by były stworzone warunki nie tylko do sprawnego generowania wartości przez przedsiębiorstwo, jej przejmowania, ale także do skutecznej obrony przed utratą wartości, a w konsekwencji do zapewnienia przedsiębiorstwu możliwości dysponowania odpowiednio dużą wartością. Niektóre postulaty dotyczące zarządzania zatrzymywaniem wartości zostaną sformułowane na podstawie modeli przedstawionych na rysunkach 1 i 2 .

Pierwszy z modeli (rys. 1) obrazuje statyczne podejście do generowania i przejmowania wartości. Nie ujęto w nim możliwych zmian w relacjach między podmiotami uczestniczącymi w rozpatrywanym procesie, które mogłyby skutkować zmianami ich statusu.

Model na rysunku 1 obrazuje proces generowania, podziału i przejmowania wartości zainicjowany przez przedsiębiorstwo A, które mając pomysł na nowy czy zmodernizowany produkt, ze względu na lukę zasobową uniemożliwiającą samodzielne zaoferowanie go klientom, nawiązuje relację z przedsiębiorstwem B. Relacja ta służy włączeniu przez B części jego zasobów do realizacji zamiaru A. Dla zapewnienia sprawnej działalności operacyjnej zasoby A i B zostały zorganizowane przez to pierwsze przedsiębiorstwo. W wyniku współpracy nowo powstały produkt może być postrzegany jako mający określoną wartość użytkową U. Dla wzbogacenia oferty, do współpracy włączono przedsiębiorstwo C, które, poprawiając walory produktu, zwiększyło jego wartość emocjonalną E. W toku współpracy przedsiębiorstwo A płaci przedsiębiorstwom B (należność $\beta$ ) i $C$ (należność $\gamma$ ) za ich zaangażowanie $\mathrm{w}$ proces wytwarzania produktu, co $\mathrm{z}$ jego punktu widzenia 


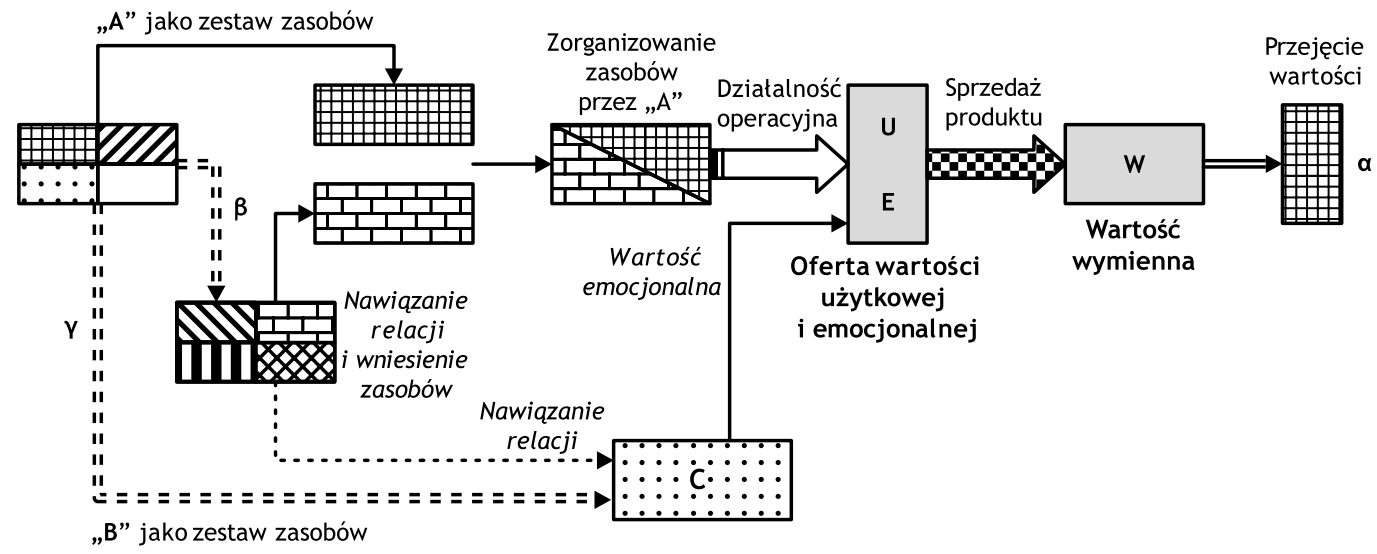

Rys. 1. Schemat procesu generowania, podziału i przejmowania wartości w ramach relacji między przedsiębiorstwami

Źródło: opracowanie wtasne na podstawie: Gulski, 2017, s. 75

stanowi koszt, zaś dla B i C jest to wartość wymienna W, która staje się wartością zatrzymaną. Do momentu sprzedaży produktu przedsiębiorstwo A ponosi koszty nadania mu właściwości oczekiwanych przez klientów. Sprzedaż produktu potwierdza spełnienie tych oczekiwań, a zarazem dostarcza przedsiębiorstwu A wartość wymienną $\alpha$, którą może ono przejąć i zatrzymać.

$\mathrm{W}$ przedstawionym modelu sytuacja przedsiębiorstw jest niezmienna. Jednak w rzeczywistości sytuacja przedsiębiorstwa $\mathrm{w}$ relacjach $\mathrm{z}$ innymi podmiotami ewoluuje. Jest dynamiczna. Kolejny model procesu generowania i przejmowania wartości przez przedsiębiorstwo ujmuje tę dynamikę i ma charakter komplementarny w stosunku do wcześniejszego.

Model obrazujący zachodzące symultanicznie procesy generowania i przejmowania wartości przez przedsiębiorstwa zaproponowali P. Verdin i K. Tackx (2015). Model ten pozwala dostrzec wyzwania pojawiające się przed nimi na określonym rynku czy w przemyśle. Zaprezentowano go na rysunku 2. Model obrazuje, w jaki sposób przekształca się sytuacja przedsiębiorstw wskutek zmian w otoczeniu oraz własnych zachowań (działań lub zaniechań). Punktem wyjścia do opisu dynamiki procesów generowania i przejmowania wartości w tym modelu jest sytuacja nazwana przez autorów „Marzenia”. Znajdują się w niej przedsiębiorstwa o utrwalonej pozycji, które jakkolwiek generują stosunkowo mało wartości, cechują się dużą wartością przejętą. Ta sytuacja jest właściwa dla przedsiębiorstw mających silną pozycję rynkową, nawet zbliżoną do monopolu, które dyskontując ją, narażają się otoczeniu czy powodują postulaty deregulacji. Atrakcyjność rynku czy przemysłu, w którym funkcjonują, może przyciągać kolejnych konkurentów, co skutkuje obniżeniem cen i zysków. Wdrożenie nowych technologii przez rywali może stanowić dodatkowe źródło poważnych zagrożeń dla podmiotów już „zadomowionych” na rynku czy w sektorze. Wskutek presji nowych konkurentów i ewentualnej deregulacji połączonych $\mathrm{z}$ brakiem odpowiedniej reakcji, przedsiębiorstwa mające uprzednio utrwaloną pozycję mogą znaleźć się w sytuacji nazwanej „Piekło”, cechującej się niewielką wartością, zarówno generowaną, jak i przejętą. Początkowo presja ze strony nowych konkurentów może być niezauważona czy zlekceważona. Zachowania pomiotów o utrwalonej pozycji mogą przybrać postać zmian regresywnych (Koźmiński, Obłój, 1989, s. 293-302) czy błędnego koła (Obłój, 1986, s. 59) i wyrażać się w wypowiedziach typu: nic nam nie grozi, zagrożenie jest tylko chwilowe, różnimy się od „nowych”. Przedłużająca się presja na ceny i zyski może doprowadzić kierownictwa przedsiębiorstw do refleksji i dostrzeżenia rzeczywistości, a w konsekwencji reakcji i podjęcia zachowań o charakterze strategicznym. Jednak może również pojawić się bezwład oraz napięcie między dążeniem do krótkookresowej optymalizacji i zmianami strategicznymi. Przedsiębiorstwa znajdujące się w fazie przejściowej między sytuacjami „Marzenia” i „Piekło” mogą podejmować zachowania o charakterze taktycznym czy operacyjnym, próbując „odwrócić” presję czy choćby opóźnić ją np.: korygując ceny, uczestnicząc w zmowach lub kartelach, dokonując restrukturyzacji i obniżając koszty, deklarując zwiększenie wartości dla klientów czy próbując tworzyć dla nich koszty zamiany, ale bez kreowania rzeczywistej lojalności klientów (zachowania właściwe dla zmian regresywnych), co w konsekwencji tylko pogarsza sytuację takich podmiotów. W skrajnych przypadkach przedsiębiorstwa znajdujące się w sytuacji „Piekło" mogą upaść lub być przejęte.

Przedsiębiorstwo, które wychodzi z sytuacji „Piekło”, znajduje się w „Koszmarze”. Charakterystyczna dla tej sytuacji jest niewystarczająca skuteczność mechanizmów przejmowania wartości w stosunku do mechanizmów jej generowania, wskutek czego przedsiębiorstwa, generując wartość, przejmują ją w niedostatecznych rozmiarach. Istota koszmaru polega zatem na tym, iż wysiłek przedsiębiorstwa nie jest rekompensowany w odpowiednim stopniu przez wartość przejętą. Poza tym P. Verdin i K. Tackx (2015) podkreślili, że rozwiązanie problemu przejmowania wartości $\mathrm{w}$ tej sytuacji nie powinno być odkładane „na później”, ponieważ w późniejszym okresie może być trudno przekonać klientów do płacenia wyższej ceny za produkt będący nośnikiem większej wartości. Jako zasadę zaproponowali, aby kształtować ceny produktów stosownie do zmian zestawu czy propozycji wartości dla klientów, co ułatwia znalezienie się w sytuacji „Niebo”. Fakt, że przedsiębiorstwo jest w sytuacji „Niebo”, nie oznacza, że może ulec 


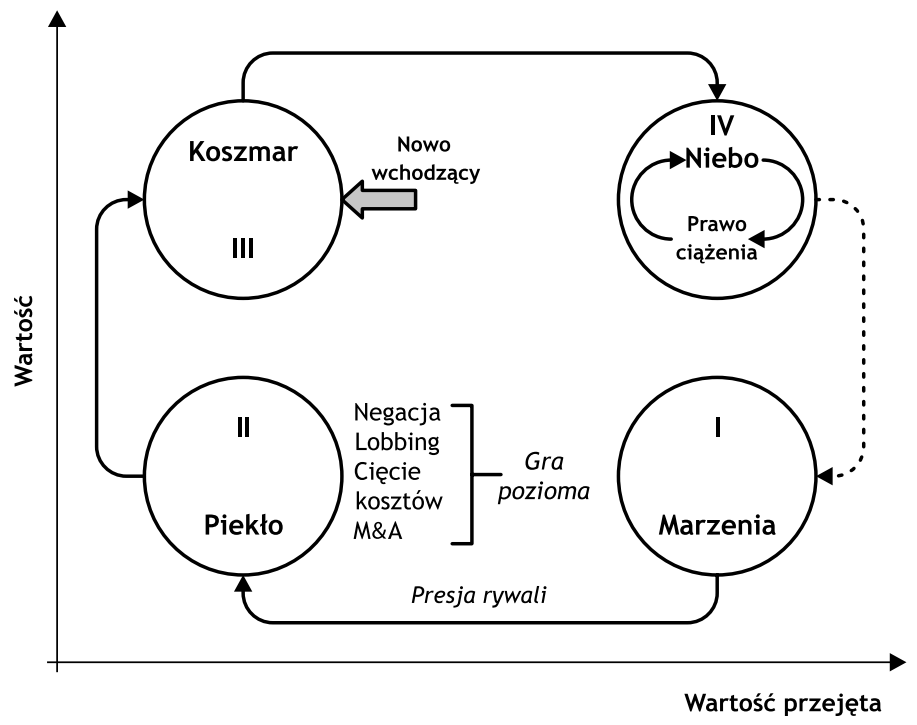

Rys. 2. Dynamika procesu generowania i przejmowania wartości Źródło: opracowanie własne na podstawie: Verdin, Tackx, 2015

pokusie spoczęcia na laurach. Entropia (nazwana na rys. 2 „prawem ciążenia”) $\mathrm{w}$ powiązaniu z przekonaniem, że wielkość zapewni utrzymanie pozycji, może doprowadzić do tego, że przedsiębiorstwo ponownie znajdzie się w sytuacji „Marzenia” (Hamel, Prahalad, 1999, s. 94 i nast.).

Na podstawie przedstawionych opisów można sformułować następującą ogólną konstatację: przedsiębiorstwo, które potrafi: a) zwiększyć wielkość różnych rodzajów wartości postrzeganych przez jego potencjalnych klientów i / lub b) zmniejszyć koszty alternatywne generowania poszczególnych rodzajów wartości może usprawnić procesy generowania wartości. Bardziej konkretnie, można wyróżnić co najmniej cztery ogólne sposoby powiększania wartości wygenerowanej przez przedsiębiorstwo (Ramu, Sunitha, 2016):

1) podejmowanie działań służących obniżeniu: a) kosztów produkcji wyrobów i / lub świadczenia usług, b) kosztów transakcji producenta;

2) implementacja działań powodujących zmniejszenie kosztów transakcyjnych konsumenta;

3) podejmowanie przedsięwzięć powodujących powiększanie popytu - działań służących: a) powiększaniu postrzeganej wartości, b) obniżaniu cen produktów komplementarnych, c) powiększaniu cen substytutów;

4) wprowadzanie na rynek nowych wyrobów i / lub usług. Obok przedstawionych działań o charakterze kierunkowym można wskazać tzw. dźwignie generowania wartości. Autorzy D.P. Lepak, K.G. Smith i M.S. Taylor (2007, s. 182) zaliczyli do nich: 1) wynalazki, 2) innowacje, 3) prace badawczo-rozwojowe, 4) tworzenie wiedzy organizacyjnej, 5) struktury, warunki społeczne i motywację oraz selekcję i trening. Jako kolejny czynnik zwiększający wartość wygenerowaną przez przedsiębiorstwo można potraktować imitacje (Posen i in., 2013).

Pierwszy z przedstawionych modeli pozwala sformułować ogólny postulat dotyczący sposobu kształtowania zasobów przedsiębiorstwa: należy to czynić w taki sposób, by zasoby umożliwiały maksymalizowanie wartości postrzeganej przez klientów. Konkretne sposoby jego realizacji zależą od specyfiki działalności prowadzonej przez przedsiębiorstwo. Ponadto można oczekiwać, że zasoby będą stwarzać warunki do wzmocnienia siły przetargowej i zdobywania przewag negocjacyjnych nad nabywcami produktów oraz nad innymi podmiotami uczestniczącymi $\mathrm{w}$ procesie generowania wartości. Zasoby przedsiębiorstwa winny umożliwiać wykorzystanie różnych mechanizmów przejmowania wartości.

Komplementarne zalecenia można sformułować na podstawie analizy dynamiki przedstawionej na rysunku 2. O ile bowiem ujęcie statyczne pozwoliło sformułować wytyczne dotyczące kształtowania zasobowej infrastruktury aktywności przedsiębiorstwa, o tyle podejście dynamiczne, koncentrując się na samej aktywności przedsiębiorstw, umożliwia określenie pożądanych zachowań o charakterze taktycznym i operacyjnym w odmiennych sytuacjach. Na rysunku 3 przedstawiono ogólną charakterystykę takich zachowań.

Nawet pobieżna analiza wskazanych na rysunku 3 zachowań przedsiębiorstw pozwala stwierdzić, że ich zainicjowanie i późniejsze kontynuowanie wymaga dysponowania przez przedsiębiorstwo specyficznymi kompetencjami. W wielu przypadkach wymagałoby to zdobycia kompetencji istotnie różniących się od dotychczasowych.

Kolejny składnik zarządzania zatrzymywaniem wartości, czyli przejmowanie wartości jest w ramach sektorów skutkiem migracji wartości i specyficznych czynników, które na nią wpływają. Można wyróżnić (Jacobides i in., 2012):

1. Czynniki ułatwiające migrację i zatrzymywanie wartości:

a) ograniczone powiązania pionowe między przedsiębiorstwami w sektorze, większa modularność i standaryzacja produktów, większa turbulencja uczestników,

b) niespokojne otoczenie technologiczne i instytucjonalne, krótszy cykl życia produktów w sektorze, mniej sztywne reguły projektowania,

c) łatwiejsze kreowanie nowych nisz, subrynków sektora, większe prawdopodobieństwo ukształtowania nowej architektury przemysłu,

d) większe zmiany potrzeb końcowych klientów i / lub tożsamości końcowych klientów. 


\begin{tabular}{|c|c|c|c|}
\hline & & \multicolumn{2}{|c|}{ Wartość przejęta } \\
\hline & & Mała & Duża \\
\hline \multirow{2}{*}{ 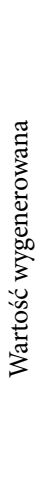 } & Duża & $\begin{array}{l}\text { Koszmar: } \\
\text { - } \text { silna koncentracja na przejmowaniu wartości } \\
\text { - poszukiwanie i wdrażanie nowych mechanizmów } \\
\text { przejmowania wygenerowanej wartości }\end{array}$ & $\begin{array}{l}\text { Niebo: } \\
\text { - antycypacyjne i permanentne ulepszanie procesów } \\
\text { generowania wartości } \\
\text { - antycypacyjne i permanentne ulepszanie przejmowania } \\
\text { wartości }\end{array}$ \\
\hline & Mała & \begin{tabular}{l}
\multicolumn{1}{c}{ Piekło: } \\
- silne nastawienie na zwiększenie wielkości \\
wygenerowanej wartości \\
- zaproponowanie nowych, nieoferowanych uprzednio \\
w sektorze rodzajów wartości \\
- skuteczniejsze stosowanie mechanizmów przejmowania \\
wartości \\
- zastosowanie nowych mechanizmów przejmowania \\
wartości
\end{tabular} & $\begin{array}{l}\text { Marzenia: } \\
\text { - } \text { silne nastawienie na zwiększenie wielkości generowanej } \\
\text { wartości } \\
\text { - dostarczanie klientom nieoferowanych wcześniej } \\
\text { rodzajów wartości } \\
\text { - poprawa walorów aktualnych produktów }\end{array}$ \\
\hline
\end{tabular}

Rys. 3. Kluczowe kierunki zachowań przedsiębiorstw w odmiennych sytuacjach z punktu widzenia generowania i przejmowania wartości Źródto: opracowanie wtasne

2. Czynniki utrudniające migrację i zatrzymywanie wartości:

a) bardziej złożone produkty, trudniejsza integracja, ważniejsza rola producentów albo integratorów systemu,

b) większe potrzeby certyfikacji i zapewnienia jakości wyrobów.

D. Lavie (2007) wyróżnił czynniki, od których zależy proporcja wartości przejętej przez przedsiębiorstwo organizujące współdziałanie co najmniej dwóch podmiotów generujących wartość: 1) względny potencjał absorpcyjny, 2) względna wielkość i charakter zasobów, 3) porozumienia kontraktowe, 4) względne zachowanie oportunistyczne w trakcie współpracy, 5) względna przewaga negocjacyjna.

Wielu autorów wskazywało siłę przetargową przedsiębiorstwa jako kluczowy czynnik, który warunkuje wielkość wartości przejętej przez każdy z podmiotów uczestniczących w jej generowaniu (Lavie, 2007). Siłę przetargową określano jako zdolność do sprzyjającej zmiany warunków porozumień, otrzymywania od partnerów ułatwień i wpływania na rezultaty negocjacji (Yan, Gray, 1994). Zmiana siły przetargowej przedsiębiorstw prowadzi do asymetrycznego przejmowania wartości i dlatego próbom partnerów wzmocnienia ich siły przetargowej można przypisać chęć zapewnienia sobie nieproporcjonalnie dużego udziału w podziale wygenerowanej wartości (Lavie, 2007).

Wydaje się, że wpływ na skuteczność przejmowania wartości przez konkretne przedsiębiorstwo ma umiejętność zidentyfikowania specyficznych czynników kształtujących proces przejmowania wartości w jego sytuacji oraz ich hierarchii, a także umiejętne kształtowanie i wykorzystanie tychże czynników.

Jak już wspomniano, sekwencja zjawisk skutkujących zawłaszczeniem wartości należnej przedsiębiorstwu składa się z powstania nierównowagi w relacjach między przedsiębiorstwami, podjęcia zachowań oportunistycznych i przywłaszczenia wartości. Obrona przed utratą wartości przez przedsiębiorstwo, ostatni ze składników zarządzania zatrzymywaniem wartości, powinna uwzględniać tę sekwencję i składać się z zachowań obronnych wobec każdego ze składników tego cyklu. Cechy zachowań obronnych przed utratą wartości (zawłaszczaniem wartości) zidentyfikowanych w przedsiębiorstwach przedstawiono w tabeli 1 .

Ze względu na to, że powstanie nierównowagi organizacyjnej inicjuje proces zawłaszczania wartości, przedsiębiorstwa winny antycypacyjnie podejmować działania prewencyjne $\mathrm{w}$ relacjach $\mathrm{z}$ różnymi podmiotami, by zabezpieczyć się przed nierównowagą i jej konsekwencjami. Takie postępowanie winno przede wszystkim uwzględniać diagnozę sytuacji przedsiębiorstwa $\mathrm{z}$ punktu widzenia narażenia na uzależnienie od innych podmiotów. Jednym z kluczowych czynników, który powoduje tego typu zagrożenie, jest niedostatek zasobów w stosunku do wymogów wynikających z prowadzonej działalności (Gulski, 2017, s. 299 i nast.). Oznacza to, że odpowiednio ukształtowane zasoby zmniejszają stopień narażenia przedsiębiorstwa na nierównowagę organizacyjną.

Wydaje się, że spełnienie wymienionych postulatów może być ułatwione przez dobór adekwatnego modelu biznesu przedsiębiorstwa.

Podsumowując powyższe uwagi, można stwierdzić, że istota zarządzania zatrzymywaniem wartości przez przedsiębiorstwo polega na umiejętnym kształtowaniu zasobów przedsiębiorstwa i ich późniejszym wykorzystywaniu do generowania i przejmowania wartości oraz obrony przed jej utratą. Należy przy tym uwzględniać sprzężenia występujące między wykorzystaniem a kształtowaniem zasobów, w celu stworzenia warunków do zaspokojenia oczekiwań interesariuszy przedsiębiorstwa (rys. 4).

\section{Podsumowanie}

Sełnienie oczekiwań różnych grup interesariuszy kie$\checkmark$ rowanych pod adresem przedsiębiorstwa i zapewnienie jego legitymizacji zależy od dysponowania odpowiednio dużą wartością, co z kolei jest warunkowane sprawnością procesu zatrzymywania wartości. W literaturze $\mathrm{z}$ zakresu zarządzania wiele uwagi poświęca się procesom generowania wartości. W tych rozważaniach można jednak dostrzec 
Tabela 1. Charakterystyka zachowań obronnych przedsiębiorstw wobec zawłaszczania wartości

\begin{tabular}{|c|c|c|c|}
\hline \multirow{2}{*}{ Kryterium opisu } & \multicolumn{3}{|c|}{ Rodzaj zachowań obronnych wobec procesu zawłaszczania wartości } \\
\hline & $\begin{array}{c}\text { Obrona przed nierównowagą } \\
\text { organizacyjną }\end{array}$ & $\begin{array}{c}\text { Obrona przed oportunizmem } \\
\text { organizacyjnym }\end{array}$ & $\begin{array}{c}\text { Obrona przed } \\
\text { przywłaszczeniem wartości }\end{array}$ \\
\hline $\begin{array}{l}\text { Istota problemów } \\
\text { związanych } \\
\text { z określonym } \\
\text { zachowaniem }\end{array}$ & $\begin{array}{l}\text { Zdominowanie przez inne podmioty, } \\
\text { permanentna słabość przetargowa } \\
\text { w relacjach z partnerami }\end{array}$ & $\begin{array}{l}\text { Narażenie na oportunizm, słabość } \\
\text { przetargowa z określoną grupą } \\
\text { partnerów }\end{array}$ & $\begin{array}{l}\text { Zagrożenie utratą wartości, } \\
\text { krótkookresowa słabość przetargowa } \\
\text { w relacjach z jednym partnerem }\end{array}$ \\
\hline $\begin{array}{l}\text { Oczekiwane skutki } \\
\text { zachowań obronnych }\end{array}$ & $\begin{array}{l}\text { Ograniczenie stopnia zdominowania } \\
\text { w relacjach, względnie trwałe } \\
\text { wzmocnienie pozycji przetargowej } \\
\text { w relacjach z większością podmiotów }\end{array}$ & $\begin{array}{l}\text { Zapobieżenie skutkom oportunizmu, } \\
\text { wzmocnienie pozycji przetargowej } \\
\text { w relacjach z podmiotami określonego } \\
\text { rodzaju i / lub należącymi do } \\
\text { określonej klasy }\end{array}$ & $\begin{array}{l}\text { Zapobieżenie utracie wartości, } \\
\text { wzmocnienie pozycji przetargowej } \\
\text { w relacjach z określonym partnerem }\end{array}$ \\
\hline $\begin{array}{l}\text { Specyficzne cechy } \\
\text { zachowań obronnych }\end{array}$ & $\begin{array}{l}\text { Nieliczne, trudne do realizacji, } \\
\text { wysoka specyfika, mogą wymagać } \\
\text { dodatkowych zdobycia nowych } \\
\text { zasobów }\end{array}$ & $\begin{array}{l}\text { Wiedza na ich temat dostępna dla } \\
\text { podmiotów z sektora, wymagają } \\
\text { dostosowania do specyfiki } \\
\text { przedsiębiorstwa }\end{array}$ & $\begin{array}{l}\text { Duży stopień typowości, łatwość } \\
\text { standaryzacji i strukturalizacji }\end{array}$ \\
\hline $\begin{array}{l}\text { Charakterystyka } \\
\text { zachowań obronnych } \\
\text { z punktu widzenia } \\
\text { zarządzania }\end{array}$ & $\begin{array}{l}\text { Zachowania strategiczne odnoszą się } \\
\text { do relacji z większością podmiotów }\end{array}$ & $\begin{array}{l}\text { Zachowania taktyczne odnoszą się } \\
\text { do relacji określonego rodzaju czy } \\
\text { z podmiotami określonej klasy, grupą } \\
\text { czy rodzajem }\end{array}$ & $\begin{array}{l}\text { Zachowania operacyjne } \\
\text { krótkookresowe, mogą odnosić się } \\
\text { tylko do jednej, konkretnej relacji }\end{array}$ \\
\hline
\end{tabular}

Źródto: Gulski, 2017 s. 296

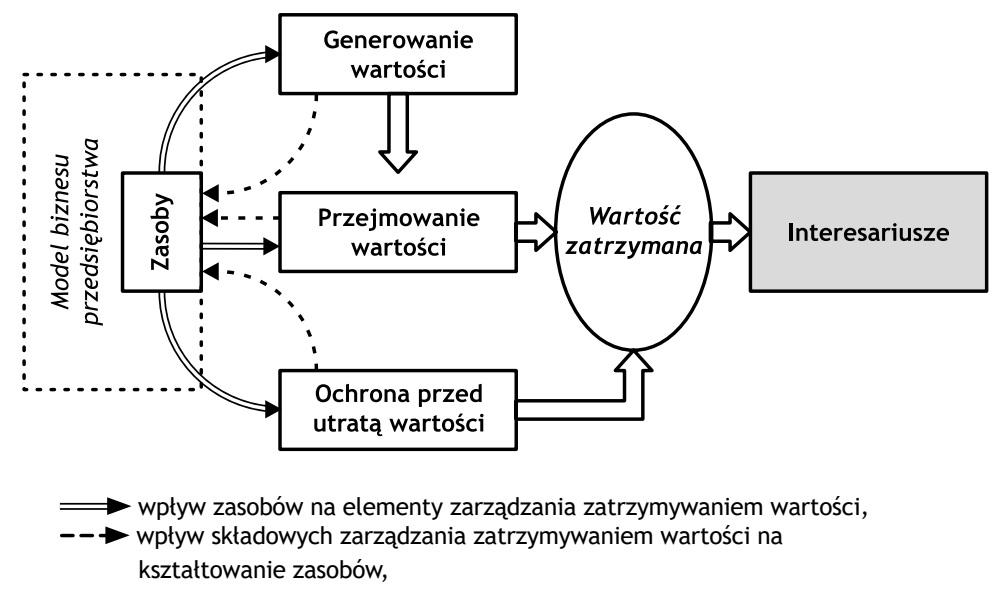

Rys. 4. Model zarządzania zatrzymywaniem wartości przez przedsiębiorstwo.

Źródło: opracowanie własne

przyjmowane implicite założenie o tożsamości między wartością wygenerowaną i tą, którą może dysponować przedsiębiorstwo. Obserwacje czynione w praktyce świadczą o tym, że jest inaczej. Wypowiedzi teoretyków zarządzania potwierdzają takie obserwacje, o czym wspomniano w artykule. Stąd można wyprowadzić postulat zintegrowanego, całościowego podejścia do procesów skutkujących zatrzymaniem wartości przez przedsiębiorstwo. Został on zrealizowany w zaprezentowanej koncepcji zarządzania zatrzymywaniem wartości przez przedsiębiorstwo. Przedstawione w artykule rozważania pozwalają wskazać podstawowe cechy tej koncepcji zarządzania:

1) koncepcja jest ukierunkowana na kształtowanie trzech procesów realizowanych $\mathrm{w}$ przedsiębiorstwie: generowania wartości, przejmowania wartości i obrony przed utratą wartości,

2) istota zarządzania zatrzymywaniem wartości sprowadza się do wykorzystania sprzężeń zwrotnych między zasobami przedsiębiorstwa a procesami wskazanymi w p. 1) w taki sposób, by zwiększyć wartość zatrzymaną przez przedsiębiorstwo,

3) koncepcja jest w fazie kształtowania, co implikuje potrzebę jej uszczegółowienia oraz opracowania metod i narzędzi, przydatnych w zarządzaniu przedsiębiorstwem - realizacja tych zadań winna stać się przedmiotem dalszej aktywności związanej z zaprezentowaną koncepcją.

W zaproponowanej koncepcji za elementy nowe w stosunku do dotychczasowych poglądów można uznać:

- podkreślenie konieczności całościowego realizowania w przedsiębiorstwie zadań i operacji składających się na generowanie wartości, przejmowanie wartości i obronę przed utratą wartości,

- wskazanie na istnienie zależności między aktywnościami składającymi się na zatrzymywanie wartości,

- sformułowanie modelu zarządzania zatrzymywaniem wartości przez przedsiębiorstwo. 
Przesłanką stosowania opisanej koncepcji jest kierowanie się przez kierownictwo przedsiębiorstwa chęcią uzyskania legitymizacji dla jego funkcjonowania przez zaspokojenie oczekiwań jego interesariuszy. Może być także stosowana przez przedsiębiorstwo, które dąży do maksymalizacji wartości, którą dysponuje przedsiębiorstwo, nawet bez intencji troski o szersze grono interesariuszy.

\section{dr hab. Bogusław Gulski \\ Uniwersytet Marii Curie-Skłodowskiej w Lublinie Wydziat Ekonomiczny \\ ORCID: 0000-0002-2681-7815 \\ e-mail: gulsbog@poczta.umcs.lublin.pl}

\section{Bibliografia}

[1] Bowman C., Ambrosini V. (2000), Value Creation Versus Value Capture: Towards a Coherent Definition of Value in Strategy, „British Journal of Management”, Vol. 11, pp. 1-15.

[2] Ellegard C., Medlin C.J., Geersbro J. (2014), Value Appropriation in Business Exchange: Literature Review and Future Research Opportunities, „Journal of Business \& Industrial Marketing", Vol. 29, No. 3, pp. 1-24.

[3] Fischer T. (2011), Managing Value Capture. Empirical Analyses of Managerial Challengesin Capturing Value, Technische Universität München, München.

[4] Gulati R., Wang L.O. (2003), Size of the Pie and Share of the Pie: Implications of Network Embeddedness and Business Relatedness for Value Creation and Value Appropriation in Joint Ventures, [in:] V. Buskens, W. Raub, C. Snijders (eds.), The Governance of Relations in Markets and Organizations, Emerald Publishing.

[5] Gulski B. (2017), Zjawisko zawłaszczania wartości a zachowania obronne przedsiębiorstw, Wydawnictwo UMCS, Lublin.

[6] Haksever C., Chaganti R., Cook R.G. (2004), A Model of Value Creation: Strategic View, „Journal of Business Ethics", Vol. 49, No. 3, pp. 291-305.

[7] Hamel G., Prahalad C.K. (1999), Przewaga konkurencyjna jutra, Business Press, Warszawa.

[8] Hensel P. (2017), Legitymizacja badań organizacji, Wyd. Naukowe PWN, Warszawa.

[9] Hoefle M. (2017), Value Extraction or Value Creation, Two Opposing Economic Practices, https://www.managerism.org/topics/value-creation/thinkpiece-no-11, access date: 21.02.2017.

[10] Hoffman A. (2015), Value Capture in Disintegrated Value Chains, Springer Gabler, Munich.

[11] Jacobides M.G., MacDuffie J.P., Tae C.J. (2012), When Value Sticks Around: Why Automobile OEMs Still Rule Their Sector, Industry Studies Association Conference, ISA, Pittsburgh.

[12] Jaki A. (2016), Prowartościowy paradygmat i koncepcja zarzadzania wartościa - mechanizmy i obszary ewolucji, „Przegląd Organizacji”, Nr 1, s. 9-15.

[13] Koźmiński A.K., Jemielniak D. (2008), Zarządzanie od podstaw, Wydawnictwa Akademickie i Profesjonalne, Warszawa.

[14] Koźmiński A.K., Obłój K. (1989), Zarys teorii równowagi organizacyjnej, PWE, Warszawa.

[15] Lavie D. (2007), Alliance Portfolios and Firm Performance: A Study of Value Creation in the US Software Industry, ,Strategic Management Journal', Vol. 28, pp. 1187-1212.
[16] Lepak D.P., Smith K.G., Taylor M.S. (2007), Value Creation and Value Capture: A Multilevel Perspective, „Academy of Management Review", Vol. 32, No. 1, pp. 180-194.

[17] Obłój K. (1986), Zarzadzanie. Ujęcie praktyczne, PWE, Warszawa.

[18] Obłój K. (2002), Tworzywo skutecznych strategii, PWE, Warszawa.

[19] Posen H.E., Lee J., Yi S. (2013), The Power of Imperfect Imitation, „Strategic Management Journal”, Vol. 34, pp. 149-164.

[20] Priem R.L. (2001), The Business Level RBV. Great Wall Or Berlin Wall? „Academy of Management Review”, Vol. 26, No. 4, pp. 499-501.

[21] Ramu U., Sunitha Y. (2016), Value Creation and Value Capturing Strategy: A Frame Work of Modern Business Approach, „Open Journal of Advances in Business \& Management", Vol. 1, No. 3, December, pp. 119-132.

[22] Raynor M.E., Mumtaz E.M. (2013), Three Rules for Making a Company Truly Great, „Harvard Business Review”, Vol. 91, No. 4, pp. 2-11.

[23] Smith J.B., Colgate M. (2007), Customer Value Creation: A Practical Framework, „Journal of Marketing Theory and Practice", Vol. 15, pp. 7-23.

[24] Strebel P., Cantale S. (2014), Is Your Company Addicted to Value Extraction? „Sloan Management Review”, No. 55, pp. 95-96.

[25] Suchman M.C. (1995), Managing Legitimacy: Strategic and Institutional Approaches, „Academy of Management Review”, Vol. 20, No. 3, pp. 571-640.

[26] Verdin P., Tackx K. (2015), Are You Creating or Capturing Value? A Dynamic Framework for Sustainable Strategy, M-RCBG Associate Working Paper Series, No. 36.

[27] Yan A., Gray B. (1994), Bargaining Power, Management Control, and Performance in United States-China Joint Ventures: A Comparative Case Study, „Academy of Management Journal”, Vol. 37, No. 6, pp. 1478-1517.

\section{Basics of Concept of Management of the Value Appropriation by the Enterprise}

\section{Summary}

The article assumes that the enterprise should strive for legitimacy in the environment, satisfying the needs of stakeholders. The purpose of the article is to formulate a concept management focused on appropriating value by an enterprise. Three main processes connected with the value in the enterprise were characterised: generating value, capturing value and defence against extraction the value. The management of appropriating value by the enterprise was defined. Moreover, a model of management appropriation the value was expressed.

Basic activities ensuring the implementation of value management by the enterprise were indicated. Next studies should concern on developing a comprehensive conception of managing of appropriating value.

\section{Keywords}

value appropriation, management 